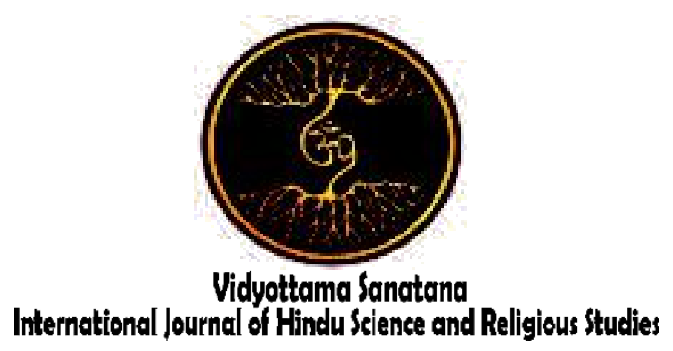

Vol. 4 No. 1 May 2020

\title{
FACTORS INFLUENCING YOGA TOURISM IN BALI: CONCEPTUAL FRAMEWORK MODEL
}

\author{
By: \\ ${ }^{1}$ Ida Ayu Kartika Maharani, ${ }^{2}$ Ida Bagus Made Wisnu Parta, ${ }^{3}$ Ida Bagus Putu Supriadi \\ ${ }^{13}$ Universitas Hindu Negeri I Gusti Bagus Sugriwa Denpasar \\ ${ }^{2}$ Universitas Dwijendra \\ E-mail : ${ }^{1}$ dayuicha@gmail.com
}

Received: March 31, 2020

Accepted: May 12, 2020

Published: May 30, 2020

\begin{abstract}
With the increasing trend of wellness tourism, as one branch of it, yoga tourism has become a new opportunity that should anticipate for tourism in Bali. Yoga tourism attempts to preserve or promote their tourist health, additionally to its usual tourist comforts. This research aims to develop a conceptual model of factors that influencing yoga tourism. By this study, some aspects of yoga tourism research reviewed to summarize the factors that affecting yoga tourism in Bali based earlier literature. The factors divided to push element and pull factor. Existing studies are limited mainly to secondary research works in yoga tourism. It recommended that future studies should empirically study the conceptual model offers by this research.
\end{abstract}

Keywords: Yoga Tourism; Wellness Tourism; Bali; Push Factors; Pull Factors

\section{INTRODUCTION}

The increasing demand for wellness tourism is experiencing an upward trend in recent years. Consistent with the worldwide Wellness Institute in 2017, the standard wellness tourism industry value is around 639 billion dollars and predicted to succeed in 912 billion dollars in 2022. Wellness tourism is tourism that promotes disease prevention tourism and is part of health tourism (Muller and Kaufmann, 2001). Holloway and Plant (1988) stated in their research that the need for tourism based on the level of needs of Maslow. Therefore the adjustment of the tourism category is also based on the level of needs such as holiday tourism, economic benefit trip, visiting family and inner circle, health tourism, religious tourism, tourism for education, and sports tourism. 
Based on Lehto et al. (2006), one among the explanations yoga tourism is becoming so popular and multiplying is due to the more pressure and stress that's felt while living lifestyle. Yoga is about self-encounter, self-enquiry, self-surveillance, and dismantling barriers to realizing the full potential of a human being (Smith et al., 2007). Satchidananda (1990) wrote a translation of Yoga Sutras of Patanjali explain that yoga become connected all pieces of the individual, i.e. physical, emotional, mental, intellectual and social.

Ambili (2016) in earlier research proved that yoga could help to be not angry, to be not anxious, to bring balance in life to the body and soul, to learn to see life in different ways and to have a fundamental understanding of the principles of yoga. It is realized that yoga impacts tourists' lives by overcoming many problems.

Bali known for being famous tourist destinations within the world must see this great opportunity. Bali recognized as one core supply tourism for Indonesia. Data of foreign tourists visiting Bali per annum is usually increasing. The portion of the contribution of foreign tourists visiting Bali for Indonesian tourism, in general, has an average portion of $33.97 \%$. The number tourist visit increasing per annum makes Bali as a top contributor for Indonesia tourism sector.

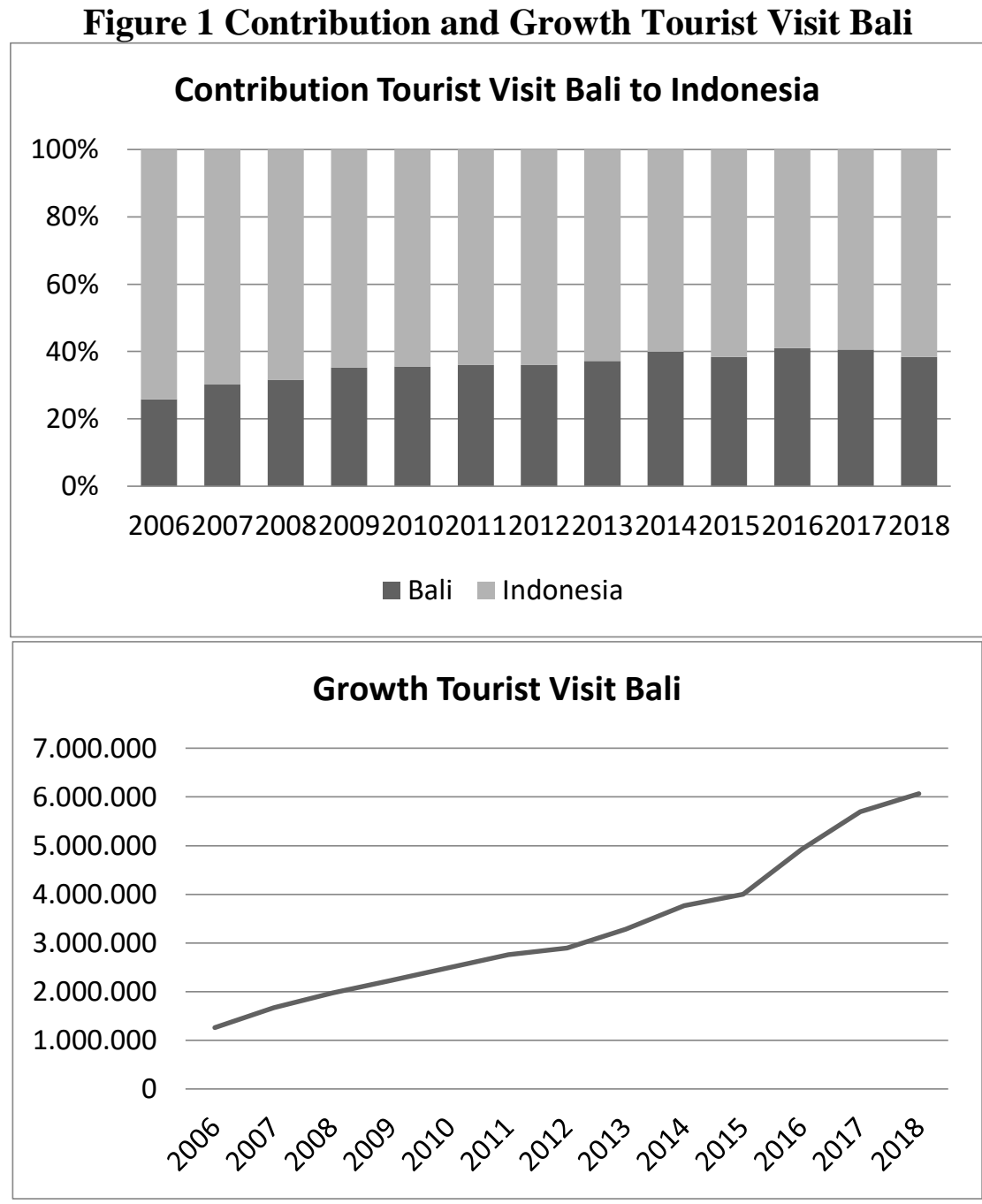

Source: Bali Tourist Statistics Book, 2018

Previous studies have found that there is in Bali. Activities like massage will decrease a change in tourist needs in wellness activities in demand within the future because it is 
familiar and may be found anywhere. This phenomenon also occurs in body and face care. In contrast, local-based spiritual tourism such as yoga, meditation, Balinese massage, consultation with a healer (Balian) is a new trend in the future (Darmawijaya et al., 2018).

The excellent opportunity for this yoga tourism also received support from the Government of the Province of Bali. Bali Governor Regulation No. 35 of 2014 concerning spiritual tourism businesses includes religious tourism, meditation tourism and yoga tourism. Yoga tourism in the regulation is defined as a tour to visit a special place to do yoga guided by a yoga teacher. Factors that encourage tourists to do yoga tourism need to be examined so that stakeholders can support these factors in the formation of strategies that can encourage the growth of yoga tourism in Bali.

\section{METHODS}

A comprehensive review of literature on the yoga tourism and growth of yoga tourism in Bali was conducted to following the specified reporting items for this study. An enquiry was performed for all published studies up to 2020 inappropriate databases, i.e. Google search, Google Scholar and Research Gate. Search terms and their combinations using the following keywords are "Yoga Tourism", "Wellness Tourism", "Bali", "Push factors", "Pull factors", "Yoga Tourism Market", and "Conceptual Models" were utilized in obtaining desired results. The research that compiled 152 articles (including duplicates) obtained. Duplicate articles were removed; titles and abstracts of the remaining 40 articles were examined to check their relevance as per the inclusion criteria (a) articles only in English and Bahasa; (b) from beginning onward; (c) covering yoga tourism; (c) cohort and observational studies. Ultimately, a complete of three articles was acknowledged, which full-text version was acquired. Hence, each of those articles was observed for information on yoga tourism, factors affecting yoga tourism, methods and results. These details are presented in Figure 2.

Figure 2. Detailed Literature Review Method

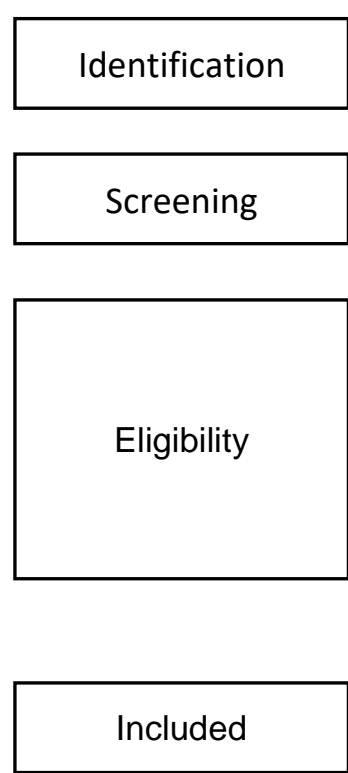

III. RESULTS AND DISCUSSION

Voigth et al. (2011) revealed that as a source of medical tourism and wellness tourism, health tourism is a core of both branches of tourism. The motive is the main

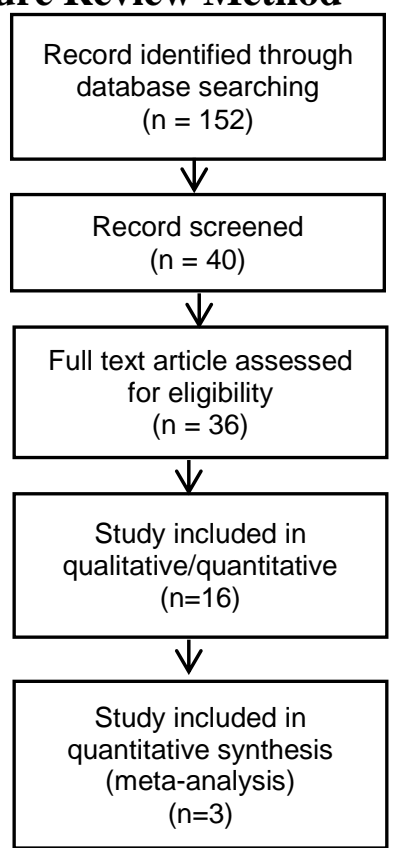

differentiator. Medical tourists have a motive to cure diseases and treat certain medical conditions, while wellness tourists have the motivation to maintain physical and spiritual health (Muller and Kaufmann, 2001). The 
wellness industry is a proactive way that can provide the goods and services sought by people who want to live healthy, fit and slow the ageing process and avoid an illness (Grénman and Räikkönen, 2015). Dunn (1972) also stated that wellness is not a condition of absence of disease but a need for purpose in life, satisfaction in life, a balance between work and rest, social relationships, a fit body, living in an environment that gives happiness. This argument explains the difference in yoga tourism as health tourism.

Altin et al. (2011), in their research, stated that medical tourism is divided into three types of cosmetic, dental and general. Cosmetic surgery is the most popular form of medical tourism, followed by travel for dental care (root canals, dental implants, aesthetics.) and general treatments such as hip, knee replacement, eye surgery, heart surgery) are other forms of medical travel. While wellness tourism is a trip to hot springs, spas resorts with retreat packages and usually choose luxurious amenities. Travel like this does not fall into the category of medical tourism but rather to wellness tourism, especially in length stay.

Most previous research categorizing yoga tourism is one of the practice to maintain physical and mental fitness (Lehto et al., 2006; Smith and Kelly, 2006; Smith and Puczko, 2009). Then Smith and Kelly (2006) added sub-classification between wellness and yoga tourism which is part of spiritual tourism. Willson (2010) and Lalonde (2012) also support this. As a mixture of earlier researches Figure 3 illustrates the typology of health tourism and where yoga tourism supposed to be.

\section{Figure 3. Typology of Health Tourism}

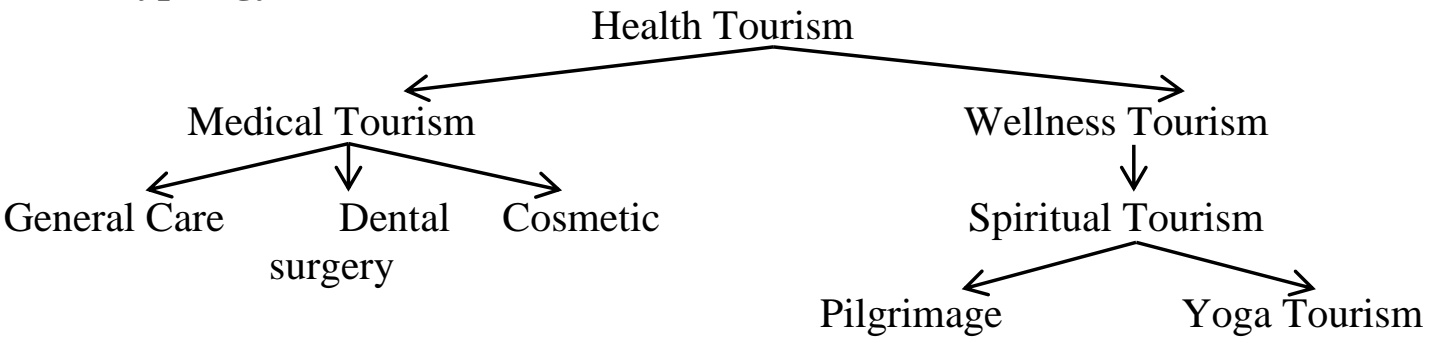

Source: Voight et al. (2011); Smith and Kelly (2006); Altin et al. (2011)

\subsection{Yoga Tourism in Bali}

Yoga becomes special interest tourism in Bali, especially Ubud, because Ubud has suitable environment for yoga, the number of tourists coming to possess quietness through yoga and therefore the number of yoga studios appearing on areas of Ubud and having different concepts, there is also one governmental business to enhance Bali tourism and stop the boredom of tourists, stakeholders like hotel, tourist travel bureau, compete to form new creation to enhance tourism in Bali, especially Ubud (Wijaya et al., 2018). The potential of yoga tourism in Bali is mixing modern yoga because of the core with the localization of Bali as its foundation. The locality of Bali is that the philosophy of yoga, spiritual culture, and native mythology that supports the event of yoga (Sutarya, 2018).

Many yoga packages are being offered in Bali. The price range is from $\$ 36$ for a twoday package until $\$ 11,577$ for the 28-day package. Comparing to India as the origin of yoga, the package offered in Rishikesh region, which is famous for its yoga tourism, the market from Bali tends to target luxury tourists because the price is so distinct. Evidence can be seen from the yoga tourism packages offered in bundles with luxury resorts with private yoga instructors. For the cheapest yoga package category in Bali, it usually does not offer meals in it, while for Rishikesh even though at a minimum price it still offers meals on the package. 
Table 1. Comparison Yoga Package Retreat Offered in Bali and India

\begin{tabular}{|c|c|c|}
\hline Length Yoga Package & Bali - Indonesia & Rishikesh - India \\
\hline 2 days & $\$ 36-\$ 550$ & $\$ 20-\$ 199$ \\
3 days & $\$ 111-\$ 1,403$ & $\$ 50-\$ 440$ \\
4 days & $\$ 39-\$ 1,949$ & $\$ 139-\$ 700$ \\
5 days & $\$ 183-\$ 2,872$ & $\$ 132-\$ 825$ \\
6 days & $\$ 109-\$ 3,248$ & $\$ 200-\$ 974$ \\
7 days & $\$ 97-\$ 4,308$ & $\$ 100-\$ 1,550$ \\
$8-10$ days & $\$ 305-\$ 5,517$ & $\$ 200-\$ 3,700$ \\
$11-30$ days & $\$ 387-\$ 11,577$ & $\$ 339-\$ 3,698$ \\
\hline
\end{tabular}

Source: www.bookyogaretreats.com accessed by the researcher in March 2020

\subsection{Motivation Yoga Tourism}

Driver for people to do travel and become tourist is called motivation (Bowen and Clarke, 2009). Also, motivation is mentioned as a process that encourages someone to do something and behave when certain circumstances (Decrop, 2006). In tourism, it is necessary to look at what motivates travelling so that it can improve the quality of tourist destination (Crompton, 1979). The urges are to conduct an in-depth study of what factors motivate a person to visit to do yoga tourism and why choosing Bali as their destination. Previous research stated that it is challenging to measure tourist motivation to travel because of the diversity of human needs, cultural differences and various methods used (Pearce and Lee, 2005).

Theories that are widely used in tourism are push and pull motivations (Awaritefe, 2004; Dann, 1981; Dunne et al., 2007; Crompton, 1979). The concept of this theory is divided into two critical factors: (1) push factors, which refer to motivations within (internal) that motivate or desire to satisfy the need to travel and (2) pull factors, which refer to attributes inherent in the area tourist destination that attracts tourists to visit (Dann, 1977). Push and pull factors are always connected simultaneously and must support one another (Bowen and Clarke, 2009). So that it can be said that there must be a match between push and pull motivational factors. For example, when a person experiences a high level of stress in his life, that person has the desire to travel to reduce stress levels and then feel more relaxed. The argument supported by the intended tourist destination to provide all things that can eliminate the stress. These two factors are not separated in one-time span but must support and complement each other (Bowen and Clarke, 2009; Crompton, 1979). Dann (1977) also added that tourist motivations are a function of both factors.

Yoga tourism research conducted by Letho et al. (2006) explains there are intrinsic factors or push factors that emerge from the tourist, so they want to find spirituality through yoga tourism such as making decisions easier, interacting with others with the same interests, improving mental health including eliminating mental illness, stress, provide relaxation and balance of life, improve physical health including relating to physical fitness and controlling negative emotions. Complementing this in terms of pull factors, Bowen and Clarke (2009) suggest that accessibility to the tourism destination, availability of yoga packages and services, tranquillity, security and stability as well as geographical considerations become a magnet for tourists doing yoga tourism to the destination.

Based on research conducted by Antara and Prameswari (2018) the most dominant push factors to visit Bali are the desire of tourists to learn new skills, increase knowledge about Balinese culture, and follow the trend to visit one of the world's best destinations namely Bali. Another push factor that needs to be considered is the desire of 
tourists to experience the lives of local Balinese people so that they can provide a better understanding of life. Relieving busyness and temporary routines (escapism) also include push factors. The dominant pull factors in the study were also the exciting natural attractions of Bali and unique culture. Bali's thick culture permeates traditions, crafts, architecture, local food, art and music, ways of life, religion, region, clothing (Shaw and Williams, 1994; Geriya, 1996). Nature of
Bali, which is in a tropical climate is also an attraction for tourists, so that yoga activities held near rivers, forests, waterfalls and places that are still beautiful, become pull factors. Supported research (Sutarya, 2018) conducted in Ubud and Sanur on the satisfaction of foreign tourists in yoga tourism; it is found that the factors of satisfaction are culture, environment and ethnicity.

Table 2 Push and Pull Factors Motivation Yoga Tourism to Bali

\begin{tabular}{|c|c|}
\hline $\begin{array}{l}\text { Push } \\
\text { The intrinsic need for tourists }\end{array}$ & $\begin{array}{l}\text { Pull } \\
\text { Attraction of Destination }\end{array}$ \\
\hline $\begin{array}{l}\text { 1. Experience and Personal Development: } \\
\text { learn yoga for the first time, increase } \\
\text { knowledge and skills of yoga, the } \\
\text { level of enthusiasm of individuals, the } \\
\text { desire to learn a new culture }\end{array}$ & $\begin{array}{l}\text { 1. Community: there is a yoga community } \\
\text { 2. Atmosphere and Climate: a calm } \\
\text { environment, close to nature, warm } \\
\text { and sunny weather. }\end{array}$ \\
$\begin{array}{l}\text { 2. Interpersonal: adventurous spirit, the } \\
\text { desire to search spirituality, the desire } \\
\text { to be friends, the need to forget the } \\
\text { difficulties for a moment (escapism) }\end{array}$ & $\begin{array}{l}\text { 3. Safety and Hygiene: situations, } \\
\text { conditions, facilities are considered } \\
\text { clean and safe }\end{array}$ \\
$\begin{array}{l}\text { 3. Prestige and benefits: feel the activity } \\
\text { of yoga is prestigious and get the } \\
\text { benefits of yoga. }\end{array}$ & $\begin{array}{l}\text { 5. Price and Service availability: the } \\
\text { facilities } \\
\text { availability of yoga packages, } \\
\text { package price and competent yoga } \\
\text { teachers }\end{array}$ \\
& $\begin{array}{l}\text { Culture and Ethnic: the uniqueness of } \\
\text { yoga which is based on Balinese } \\
\text { culture. }\end{array}$ \\
\hline
\end{tabular}

\subsection{Conceptual Framework}

To guide the course of the study, a conceptual research framework made with complied literature review earlier research conducted by Letho et al. (2006); Bowen and Clarke, 2009; Antara and Prameswari, 2018; Sutarya, 2018. Based on the variables described in table 2, the partial conceptual framework has been developed (Figure. 4) The framework provides some key variables which are the foundation for the current study. The key variables are Push Factors and Pull Factors as the independent variables. The mediating variables are Tourists Satisfaction and Tourist Motivations. Revisit Intention is a dependent variable. 
Figure 4. Conceptual Framework

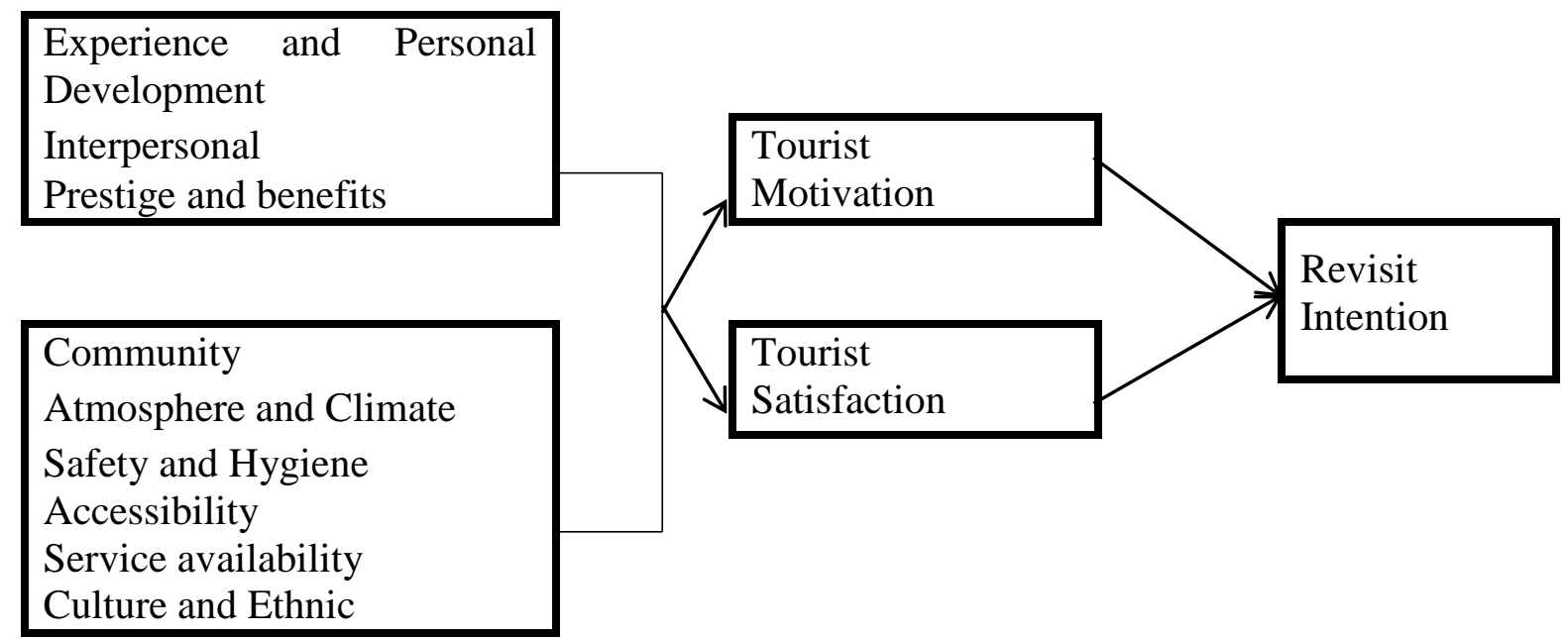

\section{CONCLUSION}

Wellness tourism, especially yoga tourism, has a rapidly growing industry globally. Bali, known as a top world-class destination, should take this opportunity. Some motivations trigger tourist to choose Bali as a yoga tourism destination. In order for marketing Bali as a unique yoga tourism destination thriving; primarily, it is essential to identify these motivations and have a strategic plan to make it optimal and sustainable.

Push and pull factors can help to develop something that a destination has to offer, including price, quality of service, infrastructure. By using this motivation theory, it can be seen which factors determine the most motivating factors for tourist to choose Bali as a destination for yoga tourism. The more comprehend the stakeholder understand the motivation, the more accurate the segmentation of yoga tourism will be targeted to be able to manage resources to support yoga tourism in Bali effectively.

\section{REFERENCES}

Altin, M., Singal, M., \& Kara, D. (2011). Conference: 16th Graduate Student Research Conference In Hospitality And TourismAt: January 6-8, 2011, Houston, TX.
Ambili, K (2016). Study on the Impact of Yoga Tourism on Tourists Visiting Kerala. Atna, J Tour Stud. 11, 1 59-69 ISSN 0975-3281.

DOI:10.12727/ajts.15.5.

Antara, M. \& Prameswari, Y.A. (2018). Push and Pull Factors of Tourists Visit the Tourism Destination of Bali, Indonesia.Journal of Tourism and Hospitality Management June 2018, Vol. 6, No. 1, pp. 112-120. https://doi.org/10.15640/jthm.v6n1a1 1

Awaritefe, Onome. (2004). Motivation and Other Considerations in Tourist Destination Choice: A Case Study of Nigeria. Tourism Geographies 6(3):303-330

Bali Tourist Statistics Book. (2018). http://disparda.baliprov.go.id/wpcontent/uploads/2019/11/BUKU-

STATISTIK-WISMAN-2018_opt.pdf

Bowen, D. \& Clarke, J. (2009). Contemporary Tourist Behavior: Yourself and Others as Tourists. Oxfordshire: CABI

Crompton, J. L. (1979). Motivation for Pleasure Vacation. Annals of Tourism Research, vol. 6 (1), pp. 408-424

Dann, Graham M.S. (1981). Tourist motivation an appraisal. Annals of Tourism Research Volume 8, Issue 2, 1981, Pages 187-219. 
Darmawijaya, I G., Tirtawati, N.M., Sekarti, N.K. (2018). The Typology of Wellness Tourism in Bali. 3rd International Conference on Tourism, Economics, Accounting, Management, and Social Science (TEAMS 2018)

Decrop, A. (2006). Vacation decision making. Oxfordshire: CABI

Dunn, Halbert. L. (1972). High-Level Welnness. Virginia: Beatty

Dunne, G., Buckley, J and Flanagan, S. (2007) City break motivation - The case of Dublin, a successful national capital. Journal of Travel and Tourism Marketing, Vol 22 (3/4), pp.95-107.

Geriya, W (1996) Pariwisata dan Dinamika Kebudayaan Lokal, Nasional, Global. Bunga Rampai Antropologi Pariwisata, Denpasar, Upada Sastra.

Grénman, Miia \& Räikkönen, Juulia. (2015). Well-being and wellness tourism Same, same but different? Conceptual discussions and empirical evidence. Matkailututkimus - The Finnish Journal of Tourism Research. 11. 725.

Holloway, C. \& Plant, R. V. (1988). Marketing for Tourism. London: Pitman Publishing

Lalonde, Angelique Maria Gabrielle (2012) Embodying asana in All New Places: Transformational Ethics, Yoga Tourism and Sensual Awakening. (Dissertation). Canada: University of Victoria.

Lee, U-I., \& Pearce, P.L. (2002). Travel motivation and travel career patterns. In Proceedings of First Asia Pacific Forum for Graduate Students Research in Tourism, 22 May, Macao (pp.17-35). Hong Kong: The Hong Kong Polytechnic University.

Lehto, X. Y., Brown, S., Chen, Y. I. and Morrison, A. M. (2006). Yoga Tourism as a Niche Within the Wellness Tourism Market. Tourism Recreation Research, vol. 31 (1), pp. 25-35.
Mueller, H. \& Kaufmann, E.L. (2001). Wellness Tourism: Market Analysis of a Special Health Tourism Segment and Implications for the Hotel Industry. Journal of Vacation Marketing, 7, 5-17. http://dx.doi.org/10.1177/135676670 100700101

Pearce, P.L., \& Lee, U. (2005). Developing the travel career approach to tourist motivation, Journal of Travel Research, 43, 226-237.

Shaw, G \& Williams, A. M. (1994). Critical Issues in Tourism : A Geographical Perspective. Oxford: Blackwell Publishers

Smith, C., Hancock, H., Blake-Mortimer, J., \& Eckert, K. (2007). A randomized comparative trial of yoga and relaxation to reduce stress and

Smith, M. and Puczko, L. (2009) Health and Wellness Tourism. Amsterdam: Elsevier

Smith, M. K. \& Kelly, C. (2006). Wellness Tourism. Tourism Recreation Research, vol. 31 (1), pp. 1-4.

Sutarya, I G. (2018). Keunggulan Kompetitif Guru Yoga Lokal dalam Pariwisata Spiritual di Bali. Denpasar: Institut Hindu Dharma Indonesia.

Voigt, Cornelia \& Brown, Graham \& Howat, Gary. (2011). Wellness tourists: In search of transformation. Tourism Review. $66.616-30$. 10.1108/16605371111127206.

Wijaya, P. U., Warto, W., Wijaya, M. (2018). The Authenticity of Yoga as Tourist Special Interest in Ubud Bali. Proceeding of 3rd International Conference on Art, Language, and Culture The Improvement of SocioCultural Community Life Through Contextual Art Education.

Willson, G. B. (2010). Exploring Travel and Spirituality: The role of travel in facilitating life purpose and meaning within the lives of individuals. PHD Thesis. Hamilton: The University of WAIKATO 